\title{
The Study of Measuring China's Agricultural Export Cost to the United States and Its Impact on Trade Growth
}

\author{
Aiping Yao ${ }^{1} \&$ Liping $\mathrm{Wan}^{1,2}$ \\ ${ }^{1}$ College of Economics and Management, Southwest University, Chongqing, P.R. China \\ ${ }^{2}$ College of Medicine Information, Chongqing Medical University, Chongqing, P.R. China \\ Correspondence: Liping Wan, College of Medicine Information, Chongqing Medical University, Chongqing \\ 400016, China. Tel: 86-139-8335-8586. E-mail: cnmaths@gmail.com
}

Received: November 8, 2014

Accepted: December 1, 2014

Online Published: January 25, 2015

doi:10.5539/ibr.v8n2p181

URL: http://dx.doi.org/10.5539/ibr.v8n2p181

\begin{abstract}
This paper is based on the studies of Andersen and Van Wincoop (2003) and Abulaiti Yiming (2013) to construct unilateral trade model to analyze the trend of China's agricultural export cost to the United States and its impact on export growth. The results show that: After joining the WTO, the trend of China's agricultural export cost to the United States is the first dropping then rising. Although the overall magnitude of change is slow, its contribution rate is great to China's agricultural export growth to the United States.
\end{abstract}

Keywords: agriculture products, gravity model, export cost, trade growth

\section{Introduction}

Since China joined the WTO, Sino-US trade has grown fast. According to Chinese customs data, Sino-US trade in goods rose to $\$ 484.7$ billion in 2012 from $\$ 80.48$ billion in 2001, an average annual growth rate of $17.55 \%$. Meanwhile, China's trade surplus to the United States was also a substantial increase, which rose to \$218.9 billion in 2012 from $\$ 28.08$ billion in 2001, an average annual growth rate of $19.81 \%$. But the Sino-US agricultural trade was very small scale, it was only $\$ 30.708$ billion even in 2012 , which was at a lower proportion of Sino-US trade in goods. The proportion accounted for $4.35 \%$ in 2001, in 2004 once dropped to 2.44 percent, after showing slow upward trend, reaching $6.34 \%$ in 2012 . And, in addition to 2004 , the China's agricultural trade to the U.S has been in deficit, and has expanded each year (Figure 1). It can be seen, on the one hand, the pace of development of Sino-US agricultural trade is behind the trade of industrial products, and the development of agricultural trade is great potential; on the other hand, the development of Sino-US agricultural trade is in imbalance, as a large agricultural country China must vigorously develop agricultural export trade to the United States. Whether China's agricultural export cost to the United States is too much to hinder China's agricultural export growth to the United States? How is Chinese agricultural export cost to the United States? What its impact on international trade growth? This paper will focus on the analysis of these issues, in the hope for a more clear understanding of China's agricultural export cost to the United States, and to provide a realistic basis and decision-making reference for the promotion of China's agricultural export to the United States.

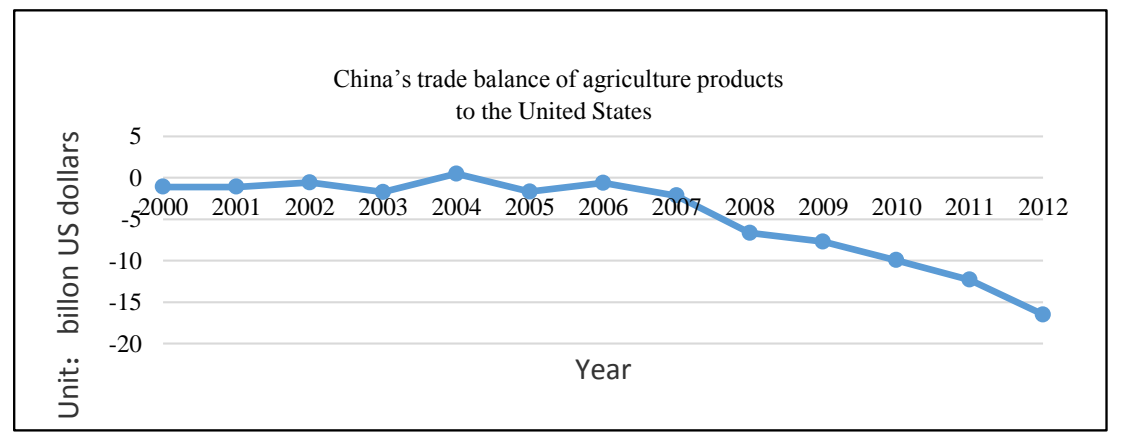

Figure 1. China's trade balance of agriculture products to the United States from 2001 to 2012 


\section{Literature Review}

\subsection{The Research on Factors Affecting Sino-US Agricultural Trade}

At present, the research on factors affecting Sino-US agricultural trade is mainly in China, the study of Chen Jiyong and Lei Xin (2008) showed that in the long term, the changes of yuan-dollar exchange rate had a long term equilibrium relationship with Sino-US agricultural trade, but in the short term equilibrium relationship was not obvious. Chen Jiyong and Sui Xiaofeng (2009) adopted the product relative competitiveness model to analyze effect of the changes in the real exchange rate, per capita growth, income and other factors to Sino-US agricultural trade relative competitiveness. Peng Kemao (2012) found that the demand ability of the United States was the main reason to promote China's agricultural export to the United States, and the differences of economy scale and resource endowment were important factor to Sino-US agricultural trade deficit.

\subsection{The Research on Trade Cost}

\subsubsection{Determination of Trade Cost}

Mccallum (1995), Rose (2000)adopted conventional gravity model to determine trade cost, but the model had defects ,such as it could cause partial results due to missing variable of trade cost, could not do comparative static analysis with the elimination of trade barriers and did not consider the impact of multilateral resistance. as the representative of scholars Anderson and Wincoop (2003) improved the traditional gravity model, established a general equilibrium model with a microscopic basis, the trade cost was determined by after the decision not in advance and the introduction of a multilateral resistance term (Novy, 2006). After Novy (2008, 2011) made model improvement and perfection. Novy's equation (2011) (equation (1)) not only overcome the shortcomings of the traditional gravity model which lacks microeconomic foundation and symmetry, and also has the theoretical basis of comparative advantage and heterogeneous enterprise. It is most frontier approach of measuring trade cost at home and abroad (Xu Tongsheng, 2012).

$$
\tau_{i j}=\left(\frac{t_{i j}}{t_{i i}} \cdot \frac{t_{j i}}{t_{j j}}\right)^{\frac{1}{2}}-1=\left(\frac{x_{i i}}{x_{i j}} \cdot \frac{x_{j j}}{x_{j i}}\right)^{\frac{1}{2[\sigma-1)}}-1
$$

Many scholars have measured the trade cost by the traditional or improved models ,such as Anderson Wincoop (2003), Novy (2006, 2008, 2011, 2013), Jacks (2011), Qian Xuefeng (2008), Xu Deyou (2010), Xu Tongsheng $(2010,2011,2012)$. But in practice there are still some flaws, Just to mention Abu Yiming (2013) puts it: First, Novy method of calculating the geometric mean of bilateral trade cost covers the difference between the cost of imports and export, while it is often different between the import cost and export cost. Second, Novy method needs to use trade partners' domestic and abroad trade data because of involving different caliber databases, while domestic trade data is difficult to obtain in practice, and generally used total output minus export instead of it. Output data is from OECD database, which often used GDP instead, and abroad trade data is often from the United Nations Database, the World Trade Database, so the data relate to a different caliber database.

\subsubsection{The Effect of Trade Cost to Trade Growth}

Krugman (1995), Freenstra (1998) thought that the decline in trade cost after World War II was one of the reasons for the rapid growth of world trade. Baier, Bergstrand (2001) studied the causes of trade growth in 16 OECD countries from 1958 to 1988. The contribution rate of revenue growth, tariffs reduction, and transportation cost decrease respectively were $67 \%, 25 \%, 8 \%$. David (2008) showed that the contribution rate of trade cost decline to world trade growth from 1870 to 1913 reached 50\%, while dropped to around 33\% from 1950 to 2000. After the 1990s, the international division of labor and trade professional development were generally perpendicular attention. Vertical specialization trade was considered to be one of the main forms of international trade, and a decline in trade cost was considered to be the catalyst of vertical specialization trade. Dixit (1982), Dear Dorff (1998), Ardnt (2000), Hanson (2003), Yi (2003), Jones and Kierzkowski (2001, 2004, 2005), Athukorala (2006), Lu Feng (2004) explored the impact of vertical specialization trade growth from the perspective of trade cost.

Based on the above research, we know that the study of factors affecting Sino-US agricultural trade is less from the perspective of trade cost, most research on trade cost is bilateral trade cost, which is loss of the difference information between export and import trade cost data, and involving different statistical models caliber. View of this, in this paper we construct the unilateral agricultural trade model that is the model of China's agricultural export cost to the United States. We measure China's agricultural export cost to the United States by this model and analyzed its impact on international trade growth, in order to identify the impact of trade cost to China's 
agricultural export to the United States, and provide realistic basis and decision-making reference for promoting China's agricultural export to the United State.

\section{The Unilateral Export Cost Model}

With reference to the view of Abulaiti Yiming (2013), based on Andersen and Van Wincoop (2003) model, we construct the unilateral export cost model. Andersen and Van Wincoop (2003) equation:

$$
\mathrm{X}_{i j}=\frac{Y_{\mathrm{i}} Y_{j}}{Y_{w}}\left(\frac{t_{i j}}{\prod_{i} P_{j}}\right)^{1-\sigma}
$$

$\mathrm{Xij}$ is the export of $\mathrm{i}$ country to $\mathrm{j}$ country. Yi is the total output of $i$ country. $Y j$ is the total output of $j$ country. Yw is the world output. tij is bilateral trade cost of $i$ country and $j$ country, Пi is the export multilateral resistance of $i$ country. $\mathrm{Pj}$ is import multilateral resistance of $\mathrm{j}$ country. $\Sigma$ is trade products' elasticity of substitution of two countries.

Let cij be the number of $\mathrm{j}$ country consuming products of $\mathrm{i}$ country. Pij is the price of $\mathrm{j}$ country consuming products of $\mathrm{i}$ country. $M j$ is the total import of $\mathrm{j}$ country, thus:

$$
\sum_{i} P_{i j} c_{i j}=M_{j}
$$

And CES total utility of $\mathrm{j}$ country:

$$
\max \left(\sum_{i} c_{i j}^{(\sigma-1) / \sigma}\right)^{\sigma /(\sigma-1)}
$$

Let $P i$ be the factory price of i country's export products to j country, so pij=pitij. And let Xi be the total export of $\mathrm{i}$ country. $\mathrm{Xw}=\Sigma \mathrm{i} X i$ is the world export. $M w=\Sigma M j$ is the total import.

(4) Formula to solve we have:

$$
\mathrm{X}_{i j}=\frac{X_{\mathrm{i}} M_{j}}{X_{w}}\left(\frac{t_{i j}}{\prod_{i} P_{j}}\right)^{1-\sigma}
$$

Assuming the two countries models, namely $i, r$ two countries, and then (5) is described its export:

$$
\mathrm{X}_{i r}=\frac{X_{\mathrm{i}} M_{r}}{X_{w}}\left(\frac{t_{i r}}{\prod_{i} P_{r}}\right)^{1-\sigma}
$$

And $\mathrm{X}_{i r}=\mathrm{X}_{i r}, t_{i r}=P_{r}=\Pi i \operatorname{lug}(6)$ available:

$$
\prod_{\mathrm{i}}^{1-\sigma}=\frac{M_{w}-M_{i}}{X_{w}}
$$

In the same way:

$$
P_{\mathrm{j}}^{1-\sigma}=\frac{X_{w}-X_{j}}{X_{w}}
$$

(7), (8) formula into (5) formula and assuming $X_{w}=M_{w}$, thus:

$$
t_{\mathrm{ij}}^{\sigma-1}=\frac{X_{i} M_{j}}{X_{i j}\left(X_{w}-M_{i}-X_{j}\right)}
$$

\section{The Measurement of China's Agricultural Export Cost to the United States}

\subsection{Data Source}

We adopt HS classification, and define agricultural products as all products from (01) chapter to (24) chapter in HS classification standards. All of its data is from the UN COMTRADE Database.

Elasticity of substitution $\sigma$ is difficult to estimate. We make it value of 8 referring to Anderson \& Wincoop (2004), Novy $(2008,2011)$ approach.

\subsection{The Measurement Results}

Measuring China's agricultural export cost to the United States by (9) formula, we can get the results as shown below: 


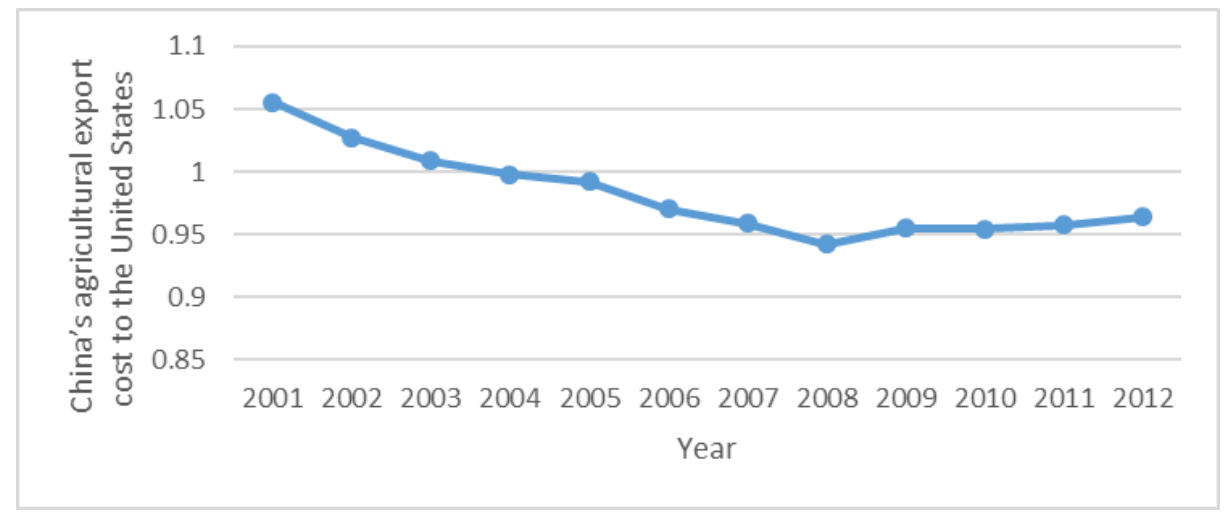

Figure 2. China's agricultural export cost to the United States from 2001 to 2012

Source: UN COMTRADE database.

In order to better illustrate the problem, we select the other nine major agricultural importers of U.S. to comparatively analysis, the export cost reducing magnitude of China and other nine major importers of U.S. from 2001 to 2012 is in the following table:

Table 1. The export cost reducing magnitude of China and other nine major importers of the U.S. from 2001 to 2012 (Unit: \%)

\begin{tabular}{lcccccccccc}
\hline country & China & Canada & Mexico & E.U & Brazil & Australia & India & Indonesia & Thailand & New Zealand \\
\hline reducing magnitude & 8.61 & 0.44 & 2.61 & 0.72 & 3.52 & 3.96 & 9.21 & 6.55 & 3.54 & 1.33 \\
\hline
\end{tabular}

Source: UN COMTRADE Database.

From Figure 2 we know after joining the WTO the trend of China's agricultural export cost to the United States decreases firstly, then increases. It declines the lowest 0.9426 in 2008 from 1.055 in 2001, then slowly rises to 0.9643 in 2012. Regardless of the rising or falling, it is very slow. But compared with the other nine countries, China's agricultural export cost to the United States declines $8.61 \%$, which is second only to India $(9.21 \%)$, and the rest are in turn Indonesia (6.55\%), Australia (3.96\%), Thailand (3.54\%), and Mexico (2.61), New Zealand (1.33), the European Union (0.72) and Canada (0.44).

The reasons of decline in China's agricultural export cost to the United States mainly are that after joining the WTO, the United States reduces tariffs on agricultural import to China, China has improved the country's infrastructure, reformed the exchange rate regime, and made the government administrative more efficient.it also indicates that the opening up after joining the WTO is more effective.

\section{The Impact of China's Agricultural Export Cost to the United States on Export Growth}

After joining the WTO, China's export to the U.S. agricultural has been grown, then what's the relationship of it with decrease in China's agricultural export cost to the United States?

Take the natural logarithm of both sides and seek an order difference to equation (2), we can get:

$$
\Delta \ln X_{i j}=\Delta \ln \left(\frac{y_{i} y_{j}}{Y^{w}}\right)+(1-\sigma) \Delta \ln t_{i j}-(1-\sigma) \Delta \ln \left(\prod_{i} P_{j}\right)
$$

(10) Equation describes China's agricultural export growth to the United States $\Delta \ln (X i j)$ is from three factors: the growth of Sino-US agricultural GDP relative to the world agricultural production $\Delta \ln \left(\frac{y_{i} y_{j}}{Y^{w}}\right)$, the changes of China's agricultural export growth to the United States $\Delta \ln t_{i j}$ and multilateral resistance change $\Delta \ln \left(\prod_{i} P_{j}\right)$. Divided the (10) equation by $\Delta \ln X i j$, we can get (11) equation:

$$
100 \%=\frac{\Delta \ln \left(\frac{y_{i} y_{j}}{Y^{w}}\right)}{\Delta \ln X_{i j}}+\frac{(1-\sigma) \Delta \ln t_{i j}}{\Delta \ln X_{i j}}-\frac{(1-\sigma) \Delta \ln \left(\prod_{i} P_{j}\right)}{\Delta \ln X_{i j}}
$$

China's agricultural export growth to the United States is broken down into three factors by (10)/ (11) equation: income growth a, export trade cost reduction b, multilateral resistance reduction $\mathrm{c}$. If China's agricultural export cost to the United States reduces (i.e. $\Delta \ln t i j<0$ ), then b contribution is positive; If the multilateral trade 
resistance decreases $(\Delta \ln (\Pi i P j)<0)$, then c contribution is negative. As a result, the agricultural export growth of China and the main competitors in the U.S. market is decomposed, and the results are shown in Table 2:

Table 2. The decomposition of agricultural export growth of China and the main competitors in the U.S. market (Unit: \%)

\begin{tabular}{lcccc}
\hline country & ETR & RGR & ETCR & MTRR \\
\hline China & 490.64 & 43.35 & 85.37 & -28.72 \\
Canada & 86.85 & 73.05 & $-1.42 \%$ & 28.36 \\
Brazil & 152.67 & 66.55 & 32.93 & 0.52 \\
Mexico & 383.45 & -163.76 & 30 & 233.77 \\
Australia & 45.76 & 90.98 & 159.9 & -150.88 \\
India & 746.06 & 92.23 & 28.75 & -20.98 \\
Indonesia & 224.11 & 60.03 & -265.17 & 305.14 \\
Thailand & 88.09 & 264.06 & -11.31 & -152.75 \\
New Zealand & 112.76 & 202.96 & 7.15 & -110.1 \\
E.U & 86.98 & 196.55 & 44.1 & -140.64 \\
\hline
\end{tabular}

Note. ETR- Export trade growth; RGR-Revenue growth rate; ETCR-The contribution rate of export trade cost 'reduction; MTRR- The contribution rate of multilateral trade resistance 'reduction.

As it can be seen from Table 2:

First, a decline in China's agricultural export cost to the United States and revenue growth are mainly reasons. The contribution rate of China's agricultural export cost to the United States is higher, and it is 85.37 percent. China's export trade grew $43.35 \%$ from revenue growth. A decline in China's multilateral trade resistance against China's agricultural export to the United States has a trade diversion effect, the contribution rate is $-28.72 \%$. Despite the contribution rate of a decline in China's agricultural export cost to the United States is $85.37 \%$, because of its multilateral resistance decreased significantly, ultimately the contribution rate of trade cost e is $37.06 \%$. $(85.37 \%-28.72 \%=56.65 \%)$.

Second, compared with other major agricultural importers of U.S. except for India, China's agricultural export growth to the United States is the fastest, and the growth rate is $490.64 \%$. However, the contribution rate of revenue growth, a decline in agricultural export cost to the United States and a decline in multilateral trade resistance of the United States are different to agricultural export growth to the United States. The agricultural export growth to the United States of Australia and china are mainly from the decline in agricultural export cost to the United States. Thailand, New Zealand, the EU, India, Canada, Brazil are mainly from revenue growth. Mexico, Indonesia are mainly from a decline in multilateral trade resistance.

\section{Discussion}

From the above study, we can get:

First, after joining the WTO, the trend of China's agricultural export cost to the United States decreases firstly, then increases. Although the overall magnitude of change is slow, compared with other major importers of the United States, China's agricultural export cost to the United States decreases greatly, only inferior to India.

Second, after joining the WTO, more than half of China's agricultural export growth to the United States are due to a decline in agricultural export cost to the United States and a decline in multilateral trade resistance.

Third, compared with other major agricultural importers of the United States, the contribution rate of China's agricultural export cost to the United States is higher, second only to Australia.

\section{Acknowledgments}

The authors are very grateful to Professor Chen Jiyong's guidance on this paper. And it is supported by the Fundamental Research Funds for the Central Universities (SWU1209384, SWU1409432) and the National Social Science Foundation (13CJY081). 


\section{References}

Anderson, J. E., \& Van Wincoop, E. (2003). Gravity with gravitas: A solution to the border puzzle. American Economic Review, 93(1), 170-192. http://dx.doi.org/10.1257/000282803321455214

Anderson, J. E., \& Van Wincoop, E. (2004). Trade costs. Journal of Economics Literature, 42(3), 691-751. http://dx.doi.org/10.3386/w10480

Bin, J. (2012). The study of China's agricultural products trade barriers from the United States. Agriculture in the World, (8), 30-32. http://dx.doi.org/10.3969/j.issn.1002-4433.2012.08.007

Hummels, D. (2001). Toward geography of trade Costs. Doctoral dissertation, Purdue University, Mimeo, America. Retrieved from http://dx.doi.org/10.2139/ssrn.160533

Jacks, D. S., Christopher, M. M., \& Novy, D. (2011). Trade Booms, Trade Busts and Trade Costs. Journal of International Economics, 83(2), 185-201. http://dx.doi.org/10.3386/w15267

Jiyong, C., \& Xiaofeng, S. (2009). The research on the Sino-US agricultural trade relatively competitive factors. Journal of Capital Economic and Trade University, (1), 16-19. http://dx.doi.org/10.3969/J.issn.1008-2700.2009.01.010

Jiyong, C., \& Xin, L. (2008). The relationship of Sino-US agricultural trade balance and the Yuan against the Dollar. The Asia-Pacific Economic, (3), 16-19. http://dx.doi.org/10.3969/j.issn.1000-6052.2008.03.010

Limão, N., \& Venables, A. J. (2001). Infrastructure, geographical disadvantage, transport costs and trade. The World Bank Economic Review, 15(3), 451-479. http://dx.doi.org/10.1093/wber/15.3.451

McCallum, J. (1995). Canada-U.S. regional trade patterns. American Economic Review, 85(3), 615-623. http://dx.doi.org/10.1111/1467-9396.00158

Novy, D. (2006). Is the iceberg less quickly? International trade costs after World War II. Master's thesis, University of Warwick, Mimeo, America. http://dx.doi.org/10.2139/ssrn.944421

Novy, D. (2011). Gravity redux: Measuring international trade costs with panel data. Doctoral dissertation, University of Warwick, Mimeo, America.

Rose, A. K. (2000). One money, one market: Estimating the effect of common currencies on trade. Economic Policy, 15(30), 7-46. http://dx.doi.org/10.3386/w7432

Tongsheng, X. (2011). Measuring the trade cost of Chinese manufacturing industries. China Industrial Economics, (7), 15-25. http://dx.doi.org 10.3969/j.issn.1004-518X.2013.01.008

\section{Copyrights}

Copyright for this article is retained by the author(s), with first publication rights granted to the journal.

This is an open-access article distributed under the terms and conditions of the Creative Commons Attribution license (http://creativecommons.org/licenses/by/3.0/). 